\title{
Composition and structure of the parasite faunas of cod, Gadus morhua L. (Teleostei: Gadidae), in the North East Atlantic Diana Perdiguero-Alonso ${ }^{1}$, Francisco E Montero ${ }^{2}$, Juan Antonio Raga ${ }^{1}$ and Aneta Kostadinova*1,3
}

Address: ${ }^{1}$ Marine Zoology Unit, Cavanilles Institute of Biodiversity and Evolutionary Biology, University of Valencia, PO Box 22085, 46071, Valencia, Spain, 2Department of Animal Biology, Plant Biology and Ecology, Autonomous University of Barcelona, Campus Universitari, 08193 , Bellaterra, Barcelona, Spain and ${ }^{3}$ Central Laboratory of General Ecology, Bulgarian Academy of Sciences, 2 Gagarin Street, 1113, Sofia, Bulgaria

Email: Diana Perdiguero-Alonso - Diana.Perdiguero@uv.es; Francisco E Montero - FranciscoEsteban.Montero@uab.es; Juan Antonio Raga - Toni.Raga@uv.es; Aneta Kostadinova* - Aneta.Kostadinova@uv.es

* Corresponding author

Published: 18 July 2008

Parasites \& Vectors 2008, I:23 doi:10.1 /86/I756-3305-I-23
Received: 4 June 2008

Accepted: 18 July 2008

This article is available from: http://www.parasitesandvectors.com/content///I/23

(c) 2008 Perdiguero-Alonso et al; licensee BioMed Central Ltd.

This is an Open Access article distributed under the terms of the Creative Commons Attribution License (http://creativecommons.org/licenses/by/2.0), which permits unrestricted use, distribution, and reproduction in any medium, provided the original work is properly cited.

\begin{abstract}
Background: Although numerous studies on parasites of the Atlantic cod, Gadus morhua L. have been conducted in the North Atlantic, comparative analyses on local cod parasite faunas are virtually lacking. The present study is based on examination of large samples of cod from six geographical areas of the North East Atlantic which yielded abundant baseline data on parasite distribution and abundance.
\end{abstract}

Materials and Methods: A total of 826 fish was sampled in the Baltic, Celtic, Irish and North seas, Icelandic waters and Trondheimsfjord (Norway) in 2002 (spring and autumn) and 2003 (spring). The gills and internal organs (oesophagus, stomach, intestine, pyloric caeca, liver, heart, spleen, gall bladder and gonads) were examined for macroparasites following a standardised protocol. The taxonomic consistency of the identification was ensured thorough the entire study.

Results: We discuss some problems in parasite identification, outline the composition of the parasite faunas in cod in the six North East Atlantic regions, provide novel data on parasite prevalence and abundance and a comparative assessment of the structure of the regional parasite faunas with respect to the higher-level taxonomic groupings, host specificity and zoogeographical distribution of the parasites. Altogether 57 different parasite forms were found including seven new host records (Diclidophora merlangi, Rhipidocotyle sp., Fellodistomum sp., Steringotrema sp., Cucullanus sp., Spinitectus sp., and Chondracanthus ornatus). The predominant groups of cod parasites were trematodes (19 species) and nematodes (13 species) including larval anisakids which comprised $58.2 \%$ of the total number of individuals.

Conclusion: Our study reveals relatively rich regional parasite faunas in cod from the North East Atlantic which are dominated by generalist parasites with Arcto-Boreal distribution. Further, it provides more detailed data on the distribution in the North East Atlantic of the majority of cod parasites which may serve as baselines for future studies on the effect of climate change. Based on the faunal comparisons, predictions can be made in relation to the structure and diversity of the parasite communities in the North East Atlantic regions studied. 


\section{Background}

The Atlantic cod, Gadus morhua L. (Teleostei: Gadidae) is one of the most important commercial fish species along the eastern and western coasts of the North Atlantic and due to this our knowledge of its life history and ecology surpasses that of most other fish species (see [1] for a review). Cod acts as intermediate, paratenic or definitive host to a large number of parasite species (107 taxa, reviewed by Hemmingsen \& MacKenzie [2]). The long list of cod parasites summarised by these authors illustrates the omnivorous nature of its diet, and its complex role within the food webs. Numerous studies on cod parasites and/or host-parasite interactions have been conducted on both sides of the North Atlantic [2]. A sizeable part of these studies focuses on various aspects of the population variability (geographical, seasonal, genetic) of anisakid nematodes which have drawn wide attention because cod hosts species of considerable economic and medical importance [3-18].

Other parasitic groups studied due to their pathological effects on cod include copepods [19,20], monogeneans [21,22], myxozoans [23] and protozoans [24]. Another group of studies is associated with taxonomy/faunistic aspects of some cod parasites: digeneans [25-33]; monogeneans [21,34]; and acanthocephalans [35-39]. A further aspect of studies on cod parasites that provides faunistic data is their use as biological markers of fish populations both in the North West Atlantic [8,40-47] and North East Atlantic regions [35,48-53].

Overall, the literature on cod parasites reveals both, differential study effort and an uneven geographical coverage. On the other hand, comparative analyses on local cod parasite faunas are virtually lacking, a series of studies by Hemmingsen and colleagues carried out off Northern Norway being a notable exception $[11,54,55]$. The present study was carried out within the framework of the multidisciplinary international project CODTRACE aimed at combining different traceability techniques to establish spawning and harvest location of G. morhua. It profited from the parasitological examination of large samples of cod collected during 2002-2003 from six regions of the North East Atlantic which yielded abundant baseline data on the distribution and abundance of macroparasites of this host in the study areas.

Here we outline the composition of the macroparasite faunas in cod in the six North East Atlantic regions studied which add to the most recent checklist of cod parasites of Hemmingsen \& MacKenzie [2] especially with respect to parasite geographical distribution. We provide novel data on species prevalence and abundance and a comparative assessment of the structure of the regional parasite faunas with respect to the higher-level taxonomic groupings, host specificity and zoogeographical distribution of the parasites.

\section{Materials and Methods Cod samples}

The study is based on 826 fish sampled in six regions of the NE Atlantic [Baltic, Celtic, Irish and North seas, Icelandic waters and Trondheimsfjord (Norway)] in 2002 (spring and autumn) and 2003 (spring). Fish represent six different stocks, according to the demarcation in management units of the International Council of Exploration of the Sea [56] (Figure 1; Table 1).

Fish were processed at the point of capture on scientific research vessels during groundfish surveys. Each fish was measured [total length (TL) and standard length (SL)] and weighted. Fish ranged from 16.5 to $119.5 \mathrm{~cm}$ in length (SL, mean $50 \pm 16.5 \mathrm{~cm}$ ) and from 0.045 to $15.3 \mathrm{~kg}$ in weight (mean $2.0 \pm 2.2 \mathrm{~kg}$ ). Visible parasites from the external and internal body surfaces were removed and preserved in $70 \%$ ethanol and the entire viscera including the gills of each fish were removed and stored frozen ($20^{\circ} \mathrm{C}$ ). These were shipped to the University of Valencia for parasitological examination.

\section{Parasite samples}

The gills and internal organs (oesophagus, stomach, intestine, pyloric caeca, liver, heart, spleen, gall bladder and gonads) were examined separately. Muscles were not available for examination. After collection of all parasite specimens, all organs were pressed individually between glass plates and further screened for parasites. Examination was carried out with the aid of high magnification stereomicroscope. All parasites were collected and preserved in $70 \%$ ethanol. Representative sub-samples of 30 specimens (when parasite numbers very high) or all specimens (when few) were prepared for detailed morphological examination and identification in Canada balsam mounts whereas the remaining specimens were identified in wet mounts. Trematodes, monogeneans and cestodes were stained with iron acetocarmine, dehydrated through an alcohol series, cleared in dimethyl phthalate and examined/identified as permanent mounts in Canada balsam. Nematodes and acanthocephalans were examined as wet mounts in saline solution or temporary mounts in clearing liquids (lactic acid or glycerine).

As a result of the sample processing skin and eyes were not subjected to examination and therefore the metacercariae [Cryptocotyle lingua (Creplin, 1825) and Diplostomum spathaceum (Rudolphi, 1819)] and cutaneous monogeneans of the genus Gyrodactylus were not collected. Furthermore, gill monogeneans of the latter genus were not detected probably due to their degradation during freezing. The abundance of the copepod Holobomolochus confu- 

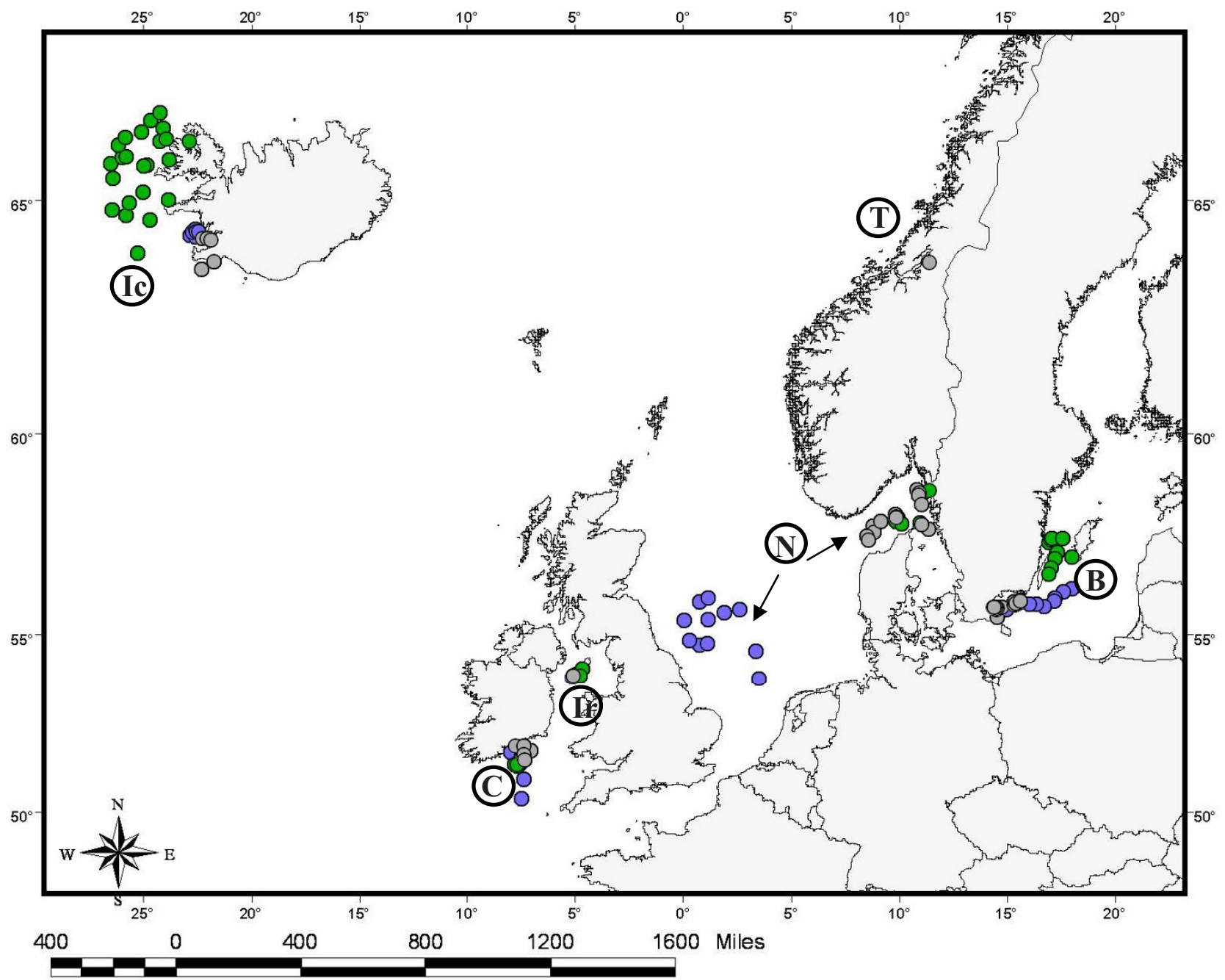

First spring sample, '02

Autumn sample, '02

Second spring sample, '03

\section{Figure I}

Sampling locations in the regions of study. Abbreviations: B, Baltic Sea; C, Celtic Sea; Ic, Icelandic waters; Ir, Irish Sea; N, North Sea; T, Trondheimsfjord.

sus from the nasal cavity of cod, as well as of some other external parasites such as hirudineans, amphipods and isopods may appear underestimated since the samples were collected in the field by non-specialists. Despite these sampling problems, the vast material of cod analysed in the present study was collected using identical sampling procedure in all regions. Parasitological examination was carried out following a standardised protocol and the taxonomic consistency of the identification was ensured thorough the entire study.

\section{Results}

\section{Comments on parasite identification and taxonomy}

The 171,821 metazoan parasites collected were identified to the lowest taxonomic level possible (most often to species level). The identification of some of the species found in this study is still controversial. Thus, Brinkman [57] pointed out that Progonus muelleri (Levinsen, 1881) has been confused with Derogenes varicus (Müller, 1774), the differences being the presence of a cyclocoel and the thicker egg shell in P. muelleri. Consequently many studies could have underestimated the presence of the latter spe- 
Table I: Sample sizes by region (areas as currently demarcated by ICES) and season

\begin{tabular}{|c|c|c|c|c|c|}
\hline Sampling area & ICES area & $\begin{array}{l}\text { Spring } \\
2002\end{array}$ & $\begin{array}{l}\text { Autumn } \\
2002\end{array}$ & $\begin{array}{l}\text { Spring } \\
2003\end{array}$ & Total \\
\hline Baltic Sea & Division IIId Subdivisions 25 and 27 & $59 a$ & $61^{b}$ & $60^{\mathrm{a}}$ & 180 \\
\hline Celtic Sea & Division VIlg & 23 & 56 & 59 & 138 \\
\hline Icelandic waters & Division $\mathrm{Va}$ & 45 & 62 & 58 & 165 \\
\hline Irish Sea & Division VIla & 60 & 52 & 24 & 136 \\
\hline North Sea & Divisions IVb and IIla & $27 c$ & $60^{d}$ & $60^{d}$ & 147 \\
\hline Trondheimsfjord & Division IVa/NCCe & & & 60 & 60 \\
\hline Total & & 214 & 291 & 321 & 826 \\
\hline
\end{tabular}

aSubdivision 25; bSubdivision 27; cDivision IVb; dDivision Illa; eNCC: Norwegian Coastal Cod stock

cies in cod. The material reported here as $D$. varicus agrees well with the morphology and metrical data for this species provided by Bray [58]. However, although D. varicus was the only species found in our study, an overestimation of its presence as in other studies is possible, especially in the cases of high parasite abundance where identification was based on representative sub-samples.

Another case of difficult identification is that of the species of the genus Stephanostomum Looss, 1899. Of the three species listed in cod by Hemmingsen \& MacKenzie [2] one, Stephanostomum baccatum (Nicoll, 1907), belongs to group 1 of Bray \& Cribb [59] [i.e. vitellarium anterior extent (\% of hindbody devoid of follicles) $<10 \%$ ] whereas the two other species, S. caducum (Looss, 1901) and S. pristis (Deslongchamps, 1824) belong to group 2 (i.e. vitellarium anterior extent $>10 \%$ ). In S. pristis from G. morhua in Danish waters Køie [60] found that, in hundreds of adult specimens, the number of circumoral spines ranged from $2 \times 18$ to $2 \times 26$, with a dominance of specimens with $2 \times 23-25$ whereas the $2 \times 18$ arrangement was rarely found. She concluded that $S$. caducum (described with $2 \times 25$ oral spines) was probably a synonym of $S$. pristis (originally described with $2 \times 18$ spines). However, Bartoli \& Bray [61] redescribed S. pristis on Mediterranean material and detected no variation in circumoral spine number. They concluded that two species were mixed in [60]. Similarly, Karlsbakk [62] found no variation in circumoral spine number in his specimens from Enchelyopus cimbrius and G. morhua from off western Norway. This author pointed out that the specimens he considered to be S. caducum from Trisopterus esmarkii and Gadiculus argenteus thori also show minimal variation in spine number, with $2 \times 24-25$ circum-oral spines. Both $S$. pristis and S. caducum were present in the total collection of cod parasites in this study. However, circumoral spines are very fragile and can be lost in frozen material or during the handling process. It was, therefore, impossible to identify at species level the numerous specimens in all samples; these are henceforth referred to as Stephanostomum spp.
A third species-identification problem concerns the pseudophyllidean cestode Parabothrium gadipollachii (Rudolphi, 1810) which is difficult to differentiate from Abothrium gadi van Beneden, 1871 (but see [63]). Although reported, the former species is infrequent in cod and common in other gadoids. The only adult cestode recovered in the present study was identified as A. gadi on the basis of its agreement with the morphological data of Williams [63]. Moreover, cross-sections confirmed the main distinctive feature at the generic level of the present material, i.e., vitelline follicles continuous throughout the length of the proglottis and intermingled with testes in $A$. gadi ( $v$ s partly cortical and partly medullary vitelline follicles, not intermingled with testes in $P$. gadipollachii, see [64]).

Larval stages pose a number of obstacles to parasite identification mostly because of their simple morphology and the fact that many of the species discriminating features are not yet present at the early stages of parasite development. One of the new host records, Rhipidocotyle sp., was found at a metacercarial stage and identified to generic level only. Larval anisakids represent a more complex case with respect to identification due to the limitations in using morphological characters [65-67] and the overall complicated taxonomy due to the presence of sibling species. Thus, Anisakis simplex (Rudolphi, 1809) is a complex of three sibling species with fairly similar morphology [68]. A. simplex A for which the name A. pegreffii was proposed, is mainly Mediterranean, whereas A. simplex sensu stricto (s.s.) (formerly differentiated as A. simplex B) has a North Atlantic distribution and A. simplex $\mathrm{C}$ was recently reported from the Pacific by Mattiucci et al. [69] (see also $[70,71]$ and references therein). Although it is possible that the third-stage larvae (L3) of Anisakis collected in the present study belong to A. simplex (s. s.), (see [71] for a detailed review on hosts and distribution) a more conservative identification was adopted, designating the specimens to A. simplex sensu lato (s. l.). 
Pseudoterranova decipiens (Krabbe, 1878), another anisakid species, also represents a species complex. Electrophoretic analyses of gene enzyme systems identified three sibling species: $P$. decipiens A, in grey seals (Halichoerus grypus) in the northeast Atlantic; $P$. decipiens $\mathrm{B}$, in harbour seals (Phoca vitulina); and $P$. decipiens $\mathrm{C}$, in bearded seals (Erignathus barbatus) [72,73]. The taxonomy of these species has recently been revised by Mattiucci \& Nascetti [71] so they should be referred to as P. krabbei Paggi et al., 1878, P. decipiens (s. s.) and P. bulbosa Kobb, 1888, respectively. A further two taxa were also later included in the $P$. decipiens species complex: Pseudoterranova azarasi (Yamaguti \& Arima, 1942) and P. cattani George-Nascimento \& Urrutia, 2000 [71]. Among the sibling species of the $P$. decipiens (s.l.) complex, present in the North East Atlantic waters, only two, P. decipiens (s. s.) and P. krabbei have been reported as parasites of $G$. morhua from the North East Atlantic (see [71] for a detailed host-parasite list).

Similarly, Nascetti et al. [74] in a multilocus electrophoretic study, recognised three species within Contracaecum osculatum (Rudolphi, 1802) species complex: C. osculatum A, occurring mainly in bearded seals in the eastern and western North Atlantic; C. osculatum B, found mainly in phocid seals in the eastern and western North Atlantic; and C. osculatum C, found in the grey seal Halichoerus grypus from off Iceland and Baltic Sea [71]. Orecchia et al. [75] added two other species, named $C$. osculatum D and C. osculatum E, found as adults in Weddell seals (Leptonychotes weddellii) in the Antarctic. Unfortunately, the above distinctions cannot be applied to the abundant larval collection in the present study due to the lack of reliable morphological features to discriminate the sibling species within $P$. decipiens and C. osculatum. Therefore, these forms were designated as $P$. decipiens sensu lato (s. l.) and C. osculatum sensu lato (s. l.).

The larval specimens Hysterothylacium (Ward \& Magath, $1917)$ in the present collection were assigned to two species. Most third-stage (L3), and all fourth-stage larvae (L4) and adults, were identified as $H$. aduncum (Rudolphi, 1802) after Berland [76] and Anderson [70], whereas the L3 forms found spirally encysted in the submucosa of the digestive tract were identified as $H$. rigidum (Rudolphi, 1809) [77]. Morphological observations in the course of this study lead to the suggestion that the larval nematodes reported as Spiruroideorum "larvae" of Janiszewska [78] by Palm et al. [79] actually represent L3 larva of H. rigidum.

All cuculanid nematodes were identified as Cucullanus cirratus Müller, 1777 except for one individual found in the stomach. The specimen was somewhat damaged which precluded its identification to the species level. However, its small oral capsule indicated that it represents a form different from both C. cirratus and Cucullanus heterochrous Rudolphi, 1802. Cucullanus sp. was, therefore, considered a new host record. The three additional new host records, namely Spinitectus sp., Fellodistomum sp. and Steringotrema sp. were only identified to the generic level due to the scarcity of the material and the problematic taxonomy of the respective groups. However, our study represents the first record of representatives of the above genera in cod [2].

The most commonly reported adult acanthocephalan in cod, Echinorhynchus gadi Zoega in Müller, 1776, which has also been reported in a large number of other teleost species [80], was found to actually represent a species complex comprising three distinct, partially sympatric species in the NE Atlantic, all occurring in cod $[39,81]$. Since the distinction of these species was inferred from molecular evidence, we were not able to discriminate E. gadi which is further referred to as E. gadi sensu lato (s. l.).

\section{General description of the parasite fauna of cod}

All fish were infected, except for three fish from the Baltic Sea. Species composition, prevalence and mean abundance of each parasite species in each region are summarized in Additional file 1 which also includes data on parasite specificity and distribution. The classification of the species with respect to the latter characteristics are based on the divisions and data of Hemmingsen \& MacKenzie [2] to which the data compiled from the literature and the Host-Parasite Database at the Natural History Museum, London [80] were added. Specificity and distribution categories were only assigned to parasites identified to species level.

Altogether 57 different parasite forms were found. Of these, 41 were identified to species level (including two species which were not considered true parasites of cod, see below), 12 were identified to generic level whereas five larval forms (one digenean, four cestodes and the copepod larvae which certainly represented juvenile stages of the copepod species recovered) were identified to family/ order (Additional file 1). Nine species were found for the first time in cod in the present study: the monogenean Diclidophora merlangi (Kuhn, in Nordmann, 1832) (described in [34]); the trematodes Rhipidocotyle sp., Fellodistomum sp. and Steringotrema sp.; the larval cestode Schistocephalus gasterostei Fabricius, 1780; the adult nematodes Cucullanus sp. and Spinitectus sp. and the copepods Acanthochondria soleae (Krøyer, 1838) and Chondracanthus ornatus Scott, 1900. Two of these cannot be considered true parasites of cod but rather part of the fish food content, namely the copepod $A$. soleae which was recovered from the stomach of one fish in a rather decomposed state and $S$. gasterostei which was found in the body cavity of a three-spined stickleback Gasterosteus aculeatus from the stomach content of one cod. The latter two species 
(labelled ' $\mathrm{D}$ ' in Additional file 1) were excluded from all comparisons. G. morhua is therefore a new host record for seven species recovered in the present study.

The predominant groups of cod parasites were trematodes (19 species) and nematodes (13 species). The other higher taxonomic groups had low representation: 8 cestodes, 7 copepods, 3 acanthocephalans, 2 hirudineans, 1 monogenean, 1 isopod and 1 amphipod. Overall, $60 \%$ of the species were represented by adult parasites. However, more than half of the parasite individuals (58.8\%) were larval forms. The majority of the larvae were anisakid nematodes which comprised $58.2 \%$ of the total number of individuals. Data in Additional file 1 reveal an overall high variation in the prevalence and abundance of the 55 parasite forms between the six study regions. Eleven species were present in all regions [the trematode Lepidapedon elongatum (Lebour, 1908); the nematodes A. simplex (s. l.), C. osculatum (s. l.), H. aduncum, H. rigidum, P. decipiens (s. l.), Ascarophis crassicollis Dollfus \& Campana-Rouget, 1956 and Capillaria gracilis (Bellingham, 1840); and the acanthocephalans Corynosoma semerme (Forssell, 1904), C. strumosum (Rudolphi, 1802) and E. gadi (s. l.)]. Three species [H. aduncum, Derogenes varicus (Müller, 1784) and A. simplex (s. l.)] showed high prevalence and abundance in the overall collection (prevalence 83.9\%, 65.6\% and $53.4 \%$, respectively; mean abundance $31.6,21.8$ and 85.3, respectively). In contrast, ten species infected only one fish each.

\section{Structure of the regional parasite faunas in cod: Higher- level taxa}

The maximum number of parasite species (37) was found in the collection from the Celtic Sea, followed by those from Icelandic waters and the Irish and North seas (36 species each). Species richness of the parasite faunas of cod was substantially lower in Trondheimsfjord and the Baltic Sea (18 and 12 species, respectively). The higherlevel taxonomic structure of the parasite faunas in cod from the 6 regions is graphically represented in Figure 2. The figure shows the relative representation in terms of both number of species and individuals of the major parasite taxonomic groupings in cod, namely, Trematoda, Cestoda, Nematoda, Acanthocephala and Copepoda. The four remaining higher-level taxonomic groups, i.e. Monogenea, Hirudinea, Amphipoda and Isopoda, were poorly represented, both in terms of species and individuals, and were omitted for clarity.

The species representation was very similar in all regions except for the Baltic Sea and Trondheimsfjord where nematodes represented a distinctly higher proportion of all species and cestodes were absent (Figure 2A,B). The four other regional faunas (i.e. in cod from Celtic, Irish and North seas and Icelandic waters) exhibited similar rich- ness of the higher taxa groupings (Figure 2C-F). The above two distinct faunas also showed marked differences with respect to the relative abundance of the higher taxonomic groups. Although nematodes were the richest taxon in the Baltic Sea collection, the high numerical dominance of acanthocephalans was the most distinctive trait of the cod parasite fauna in this region. Three species [E. gadi (s. l.), C. semerme and C. strumosum] represented nearly $64 \%$ of all parasite individuals in the Baltic Sea collection (Figure 2G). On the other hand, Trondheimsfjord fauna was distinct in the exceptionally high relative abundance of trematodes $(86.4 \%$, see Figure $2 \mathrm{H}$ ) which was mainly due to two species with similar high prevalence and abundance, L. elongatum and Lepidapedon rachion (Cobbold, 1858), which accounted for $67 \%$ and $19 \%$ of all individuals, respectively. Another characteristic feature of the Trondheimsfjord fauna was the low representation of larval nematodes and the numerical dominance of adult nematodes. Thus, two species, C. gracilis and C. cirratus (accounting for 7\% and 5\%, of the total parasite number, respectively) represented $53.2 \%$ and $41.8 \%$, of all nematodes in this collection, respectively.

Overall, the taxonomic structure of the regional parasite faunas based on the relative abundance of the higher taxa (Figure 2G-L) differed substantially from that based on species richness (Figure 2A-F). A much higher representation of nematodes was revealed in the four regions which exhibited similarity with respect to the species richness structure of the faunas (i.e. Celtic, Irish and North seas and Icelandic waters). These could be grouped in pairs with respect to the relative abundance of the numerically dominant taxa: (i) the faunas of Celtic Sea and Icelandic waters which exhibited substantially elevated numbers of nematode individuals (Figure 2I,J); and (ii) the faunas of Irish and North seas which had higher proportions of trematode individuals (Figure $2 \mathrm{~K}, \mathrm{~L}$ ).

Nematodes represented over $85 \%$ of individual parasites in the Celtic Sea collection. The most representative species were A. simplex (s. l.), H. aduncum and C. osculatum (s. l.) which comprised $42 \%, 24 \%$ and $5 \%$, respectively, of the total nematode abundance. Trematodes were less abundant when compared to the faunas of the second group (i.e. Irish and North seas, $11 \%$ of all parasites). $D$. varicus, H. communis Odhner, 1905 and Stephanostomum spp. accounted for $8 \%, 2 \%$ and $1 \%$ of all parasite individuals, respectively and represented $74.7 \%, 15.9 \%$ and $7 \%$ of all trematodes. The parasite fauna of cod in Icelandic waters was very similar to that of the Celtic Sea in terms of proportions of nematodes and trematodes ( 88 and $11 \%$ of all individuals, respectively). The most abundant nematodes were (as in the Celtic Sea collection) A. simplex (s. l.), H. aduncum and C. osculatum (s. l.) which comprised $61 \%, 12 \%$ and $10 \%$, respectively, of all individuals. The 
A

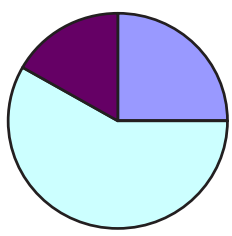

B

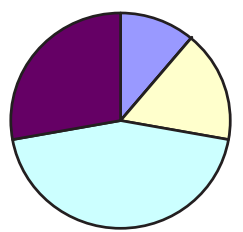

C

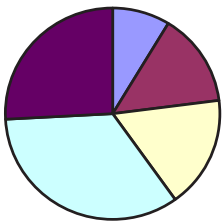

D

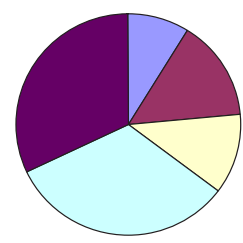

E

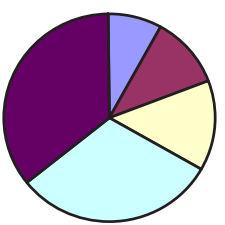

F

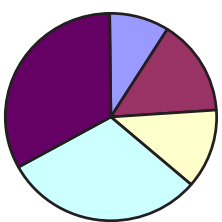

G

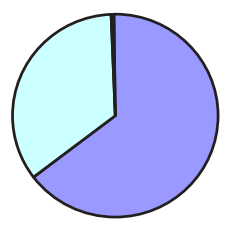

$\mathrm{H}$

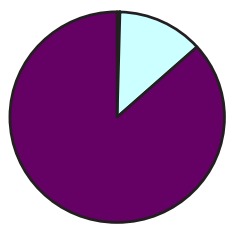

I

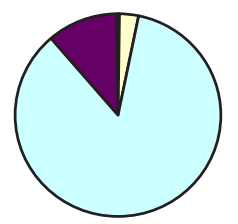

J

Icelandic waters

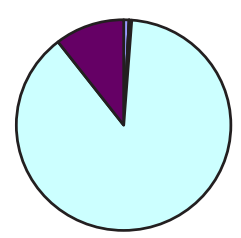

K



L

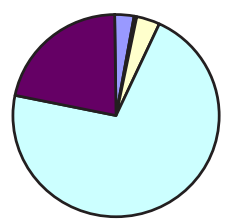

$\square$ ACANTHOCEPHALA

$\square$ CESTODA

$\square$ COPEPODA

$\square$ NEMATODA

$\square$ TREMATODA

Figure 2

Taxonomic structure of the parasite faunas of $G$. morhua in the six North East Atlantic regions with respect to relative species richness $(A-F)$ and relative abundance $(G-L)$ of the higher parasite taxa. 
most abundant trematode species in the Icelandic waters fauna was D. varicus which represened $10 \%$ of all individuals.

The cod parasite fauna of the Irish Sea was characterised by the higher numerical representation of trematodes (39\%) and a comparatively low relative abundance of nematodes which comprised $57 \%$ of all parasites (Figure $2 \mathrm{~K})$. The trematodes D. varicus, H. communis and Stephanostomum spp. comprised $29 \%, 7 \%$ and $2 \%$ of all parasites, respectively. Although the most widespread and abundant nematode species were roughly the same as in the Celtic and Icelandic faunas, their proportions of the total abundance differed. H. aduncum,C. osculatum (s. l.), Ascarophis morrhuae Van Beneden, 1871 and A. simplex (s. l.) accounted for $31 \%, 9 \%, 7 \%$ and $4 \%$ of all parasites, respectively.

The parasite fauna of the North Sea cod could be considered intermediate between the Irish Sea and the other two (i.e. Celtic Sea and Icelandic regional faunas) with respect to the relative trematode abundance which accounted for nearly $22 \%$ of parasites. D. varicus, H. communis and Stephanostomum spp. accounted for $13 \%, 4 \%$ and $4 \%$, respectively, of all forms in the North Sea collection whereas nematodes comprised $70 \%$ of all parasite forms. Again, the most common and abundant species were almost the same as in the Irish Sea fauna, but their relative proportions differed. The nematodes A. simplex (s. l.), H. aduncum, A. crassicollis and C. osculatum (s. l.) represented $29 \%$, $24 \%, 9 \%$ and $1 \%$ of all parasites, respectively.

The above distinctions of the regional parasite faunas with respect to the higher taxonomic level structure translated into a similar but more refined picture at the species level, as revealed by a cluster analysis using the similarity matrix (Bray-Curtis similarity) based on species prevalence (Figure $3 \mathrm{~A}$ ) and abundance (Figure 3B). The major differences between regions observed at the higher taxonomic level appeared valid in the species similarity analysis in that the Baltic Sea and Trondheimsfjord faunas were most dissimilar whereas the four other regions formed a cluster at high similarity levels $(72.2 \%$ and $58.5 \%$ for matrices based on prevalence and mean abundance, respectively). However, the grouping within the latter differed from that described above on the basis of the higher-level parasite representation. The faunas of North, Celtic and Irish seas formed a group at high similarity levels $(79.7 \%$ and $72.2 \%$ for matrices based on prevalence and mean abundance, respectively) whereas the parasite fauna of cod in Icelandic waters was somewhat distinct and occupied an intermediate position between this group and the Trondheimsfjord/Baltic Sea faunas. The latter two joined at low similarity levels (prevalence data $53.6 \%$ and $41.6 \%$; abundance data $29.6 \%$ and $21.9 \%$, respectively).

\section{Structure of the regional parasite faunas in cod: Host specificity of parasites}

The classification of Hemmingsen \& MacKenzie [2] was generally followed with respect to host specificity of cod parasites. No host specific parasites were found in this study. In fact, very few specific parasites are recognized in this host species [2]. Therefore two main groups are recognised here: (i) parasite species reported from cod and other gadoid fish species (gadoid specialists, labelled 'GS' in Additional file 1); and (ii) parasite species reported from a wider range of host species (generalists, labelled ' $G$ ' in Additional file 1). Hemmingsen \& MacKenzie [2] considered an additional 'accidental species' category (labelled ' $\mathrm{A}$ ' in Additional file 1) but stressed that this is an arbitrary decision and that 'accidental species' can also be placed in the 'generalist species' category due to their low specificity behaviour. This suggestion was followed in the present study for the species not listed by the latter authors.

Generalist parasites comprised the majority of the cod parasite fauna ( 40 species which accounted for $85 \%$ of all individuals) whereas gadoid specialist were poorly represented ( 12 species, $15 \%$ of all parasite individuals). The three species considered as accidental made up a minute proportion of the species and individuals. The structure of the six regional faunas in terms of parasite specificity illustrated in Figure 4 revealed that generalist species dominate over gadoid specialists with respect to both relative richness and abundance. This dominance was most expressed in the fauna of the Baltic Sea where only two gadoid specialist species $(16.7 \%$ of the species) were present (the trematode L. elongatum and the nematode $A$. crassicollis. These also had very low abundance $(0.4 \%$ of all individuals). The parasite faunas of the other low salinity region, Trondheimsfjord, exhibited an opposite pattern, i.e. the highest, especially with respect to abundance, representation of the gadoid specialists' category (Figure 4). Six species of this category, the trematodes L. elongatum and $L$. rachion, the nematodes $A$. morrhuae and C. cirratus, and the copepods Clavella adunca (Strøm, 1762) and Holobomolochus confusus (Stock, 1953), represented 33.3\% of the species and $91.3 \%$ of the individuals found in this collection.

The other four regions (Celtic, Irish and North seas and Icelandic waters) showed similar proportions and shared the same gadoid specialist species. Seven gadoid specialists were common for the four regions: L. elongatum, Stephanostomum spp., A. gadi, A. morrhuae, A. crassicollis, C. cirratus and C. adunca. Three species, Prosorynchoides gracilescens (Rudolphi, 1819), L. rachion and Ascarophis filiformis Polyansky, 1952 were present in the parasite faunas of cod from Celtic and Irish seas and Icelandic waters but absent in the North Sea fauna. However, gadoid special- 


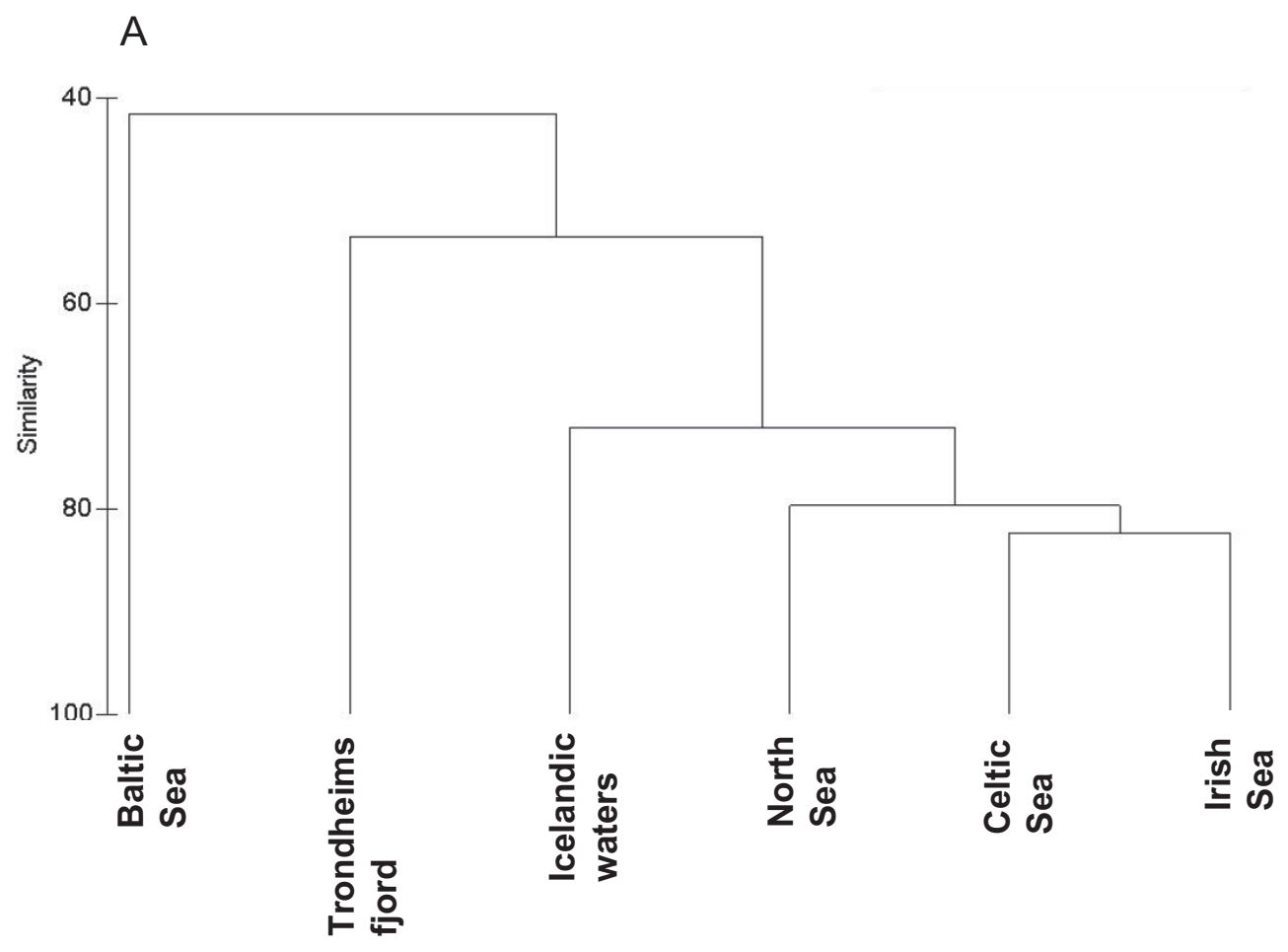

B

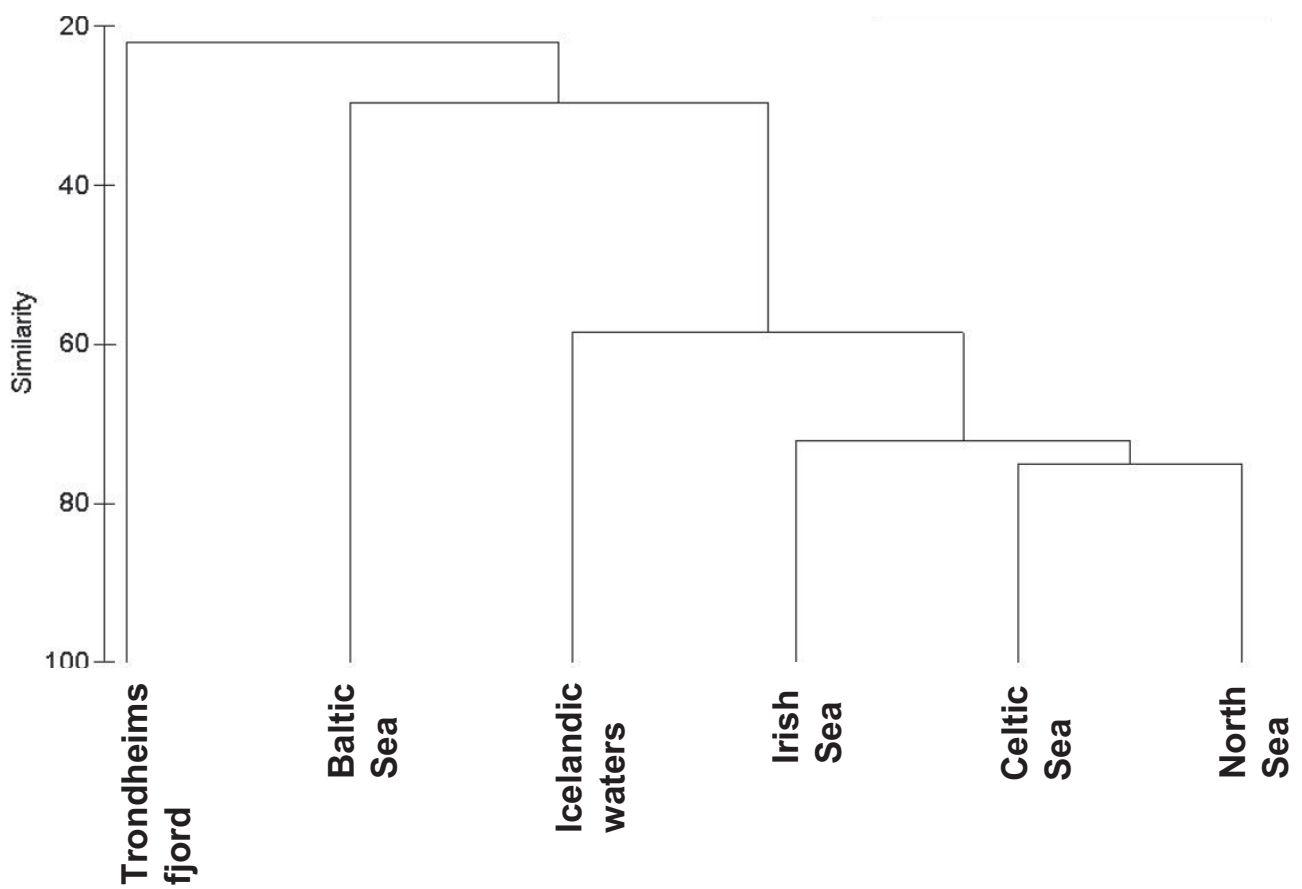

Figure 3

Cluster analysis dendrogram (group-average linkage) of the parasite faunas of G. morhua in the six North East Atlantic regions, using Bray-Curtis similarity matrices based on species prevalence (A) and mean abundance (B). 

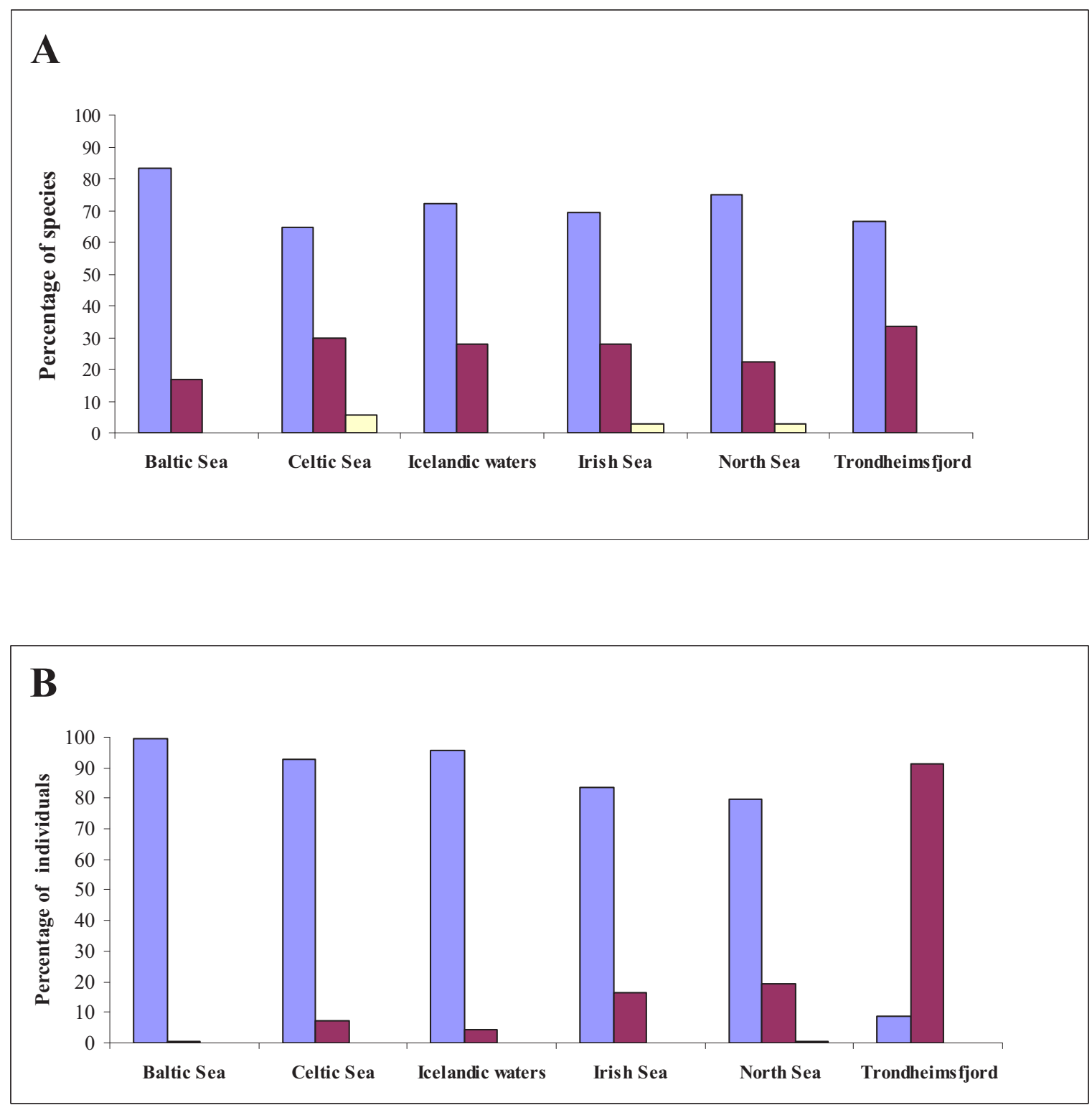

Figure 4

Relative richness $(A)$ and abundance $(B)$ structure of the parasite faunas of $G$. morhua in the six North East Atlantic regions with respect to host specificity of the parasites. 
ists were numerically better represented in the Irish and North Sea faunas as compared to the Celtic Sea and Icelandic waters faunas (16.4 and $19.5 \%$ of individuals $v s 7.2$ and $4.3 \%$, respectively, see Figure $4 \mathrm{~B})$.

\section{Structure of the regional parasite faunas in cod: Zoogeographical distribution of parasites}

Although the zoogeographical groupings of Hemmingsen \& MacKenzie [2] are rather general and related to the geographical distribution of cod only, their classification was followed to ensure the consistency of the comparisons. Parasite species were therefore split into three categories with respect to their geographical distribution: (i) ArcticBoreal species (labelled 'A-B' in Additional file 1) which 'infect cod in the northern part of its distribution but not in southern warmer waters'; (ii) Boreal species (labelled ' $\mathrm{B}$ ' in Additional file 1) whose distributions 'overlap that of cod and extend beyond it to more temperate southern waters'; and (iii) species of worldwide distribution (labelled ' $\mathrm{W}$ ' in Additional file 1) which have been reported from many different parts of the world. The category 'not applicable' (labelled 'NA' in Additional file 1) refers to taxa not identified to species level.

Due to its wide geographical extent our study added new data on the distribution of most species infecting cod in the North Eeast Atlantic (Additional file 1). Among these is the new host record, the monogenean D. merlangi found in the Celtic and North seas. This species was also recorded in the Arctic (samples from the Natural History Museum, London examined by Perdiguero-Alonso et al. [34]; see also [82]), which leads us to consider its distribution as Arctic-Boreal following the definitions of Hemmingsen \& MacKenzie [2]. The hemiurid Hemiurus luehei Odhner, 1905 (not reported by Hemmingsen \& MacKenzie [2]) actually belongs to the Boreal group (found in Irish and North seas in our study, see also [83]). Hemmingsen \& MacKenzie [2] considered that A. simplex (s. s.) which has only been reported from cod $[69,71]$, has a northern hemisphere distribution (within the worldwide category) in both the Atlantic and Pacific Oceans. However, recent data suggesting that of the three sibling species only A. simplex B has a North Atlantic distribution [68] and the present data (see Additional file 1) suggest that the anisakid larvae in cod in the North East Atlantic exhibit an Arctic-Boreal distribution.

The hirudinean Johanssonia arctica (Johansson, 1899) was considered a low Arctic species. Although we found this species in cod from Icelandic waters only, data by Appy \& Dadswell [84] suggest that it has an Arctic-Boreal distribution. The copepod species recovered in cod for the first time in our study, C. ornatus, appears to have a worldwide distribution (see [85]) whereas the isopode Gnathia elongata (Krøyer, 1847) should be considered an Arctic-Boreal species (see also [86]). On the other hand, the present study confirmed the classification of six species as Boreal by Hemmingsen \& MacKenzie [2]: Prosorhynchoides gracilescens (Rudolphi, 1819), Lepidapedon rachion (Cobbold, 1858), Opechona bacillaris (Molin, 1859), A. gadi, H. rigidum and C. strumosum; these were also found in Icelandic waters in the course of the study.

In all regions, the best-represented group in terms of parasite species was the Arctic-Boreal (Additional file 1; Figure $5 \mathrm{~A}-\mathrm{F}$ ). Roughly $20 \%$ of the species were Boreal, and the reminder had worldwide distribution except for the Baltic Sea fauna which lacked species of the latter category. The relative abundance of the species with ArcticBoreal distribution was distinctly higher (Figure 5G-L). The latter group dominated in faunas of the Baltic Sea, Trondheimsfjord and Icelandic waters representing $87 \%$, $80 \%$ and $89 \%$ of all individuals, respectively).

Of the 11 parasite species present in all regions studied, nine had an Arctic-Boreal distribution [L. elongatum, A. simplex (s. l.), C. osculatum (s. l.),H. aduncum, P. decipiens (s. l.), C. gracilis, C. semerme and E. gadi (s. l.)] and two species (H. rigidum and C. strumosum) had Boreal distributions. The relative abundance of the Boreal species was higher in the Trondheimsfjord fauna (19\% of all individuals) than in the other regions (range 9-13\% of all individuals) except for the parasite fauna of cod in Icelandic waters which showed a negligible proportion of this distribution category ( $0.1 \%$ of all individuals). The relative abundance of species with worldwide distribution was highest in the Irish Sea fauna (32\% of all individuals). In contrast, Trondheimsfjord fauna had very few individuals with worldwide distribution ( $0.5 \%$ of all individuals) because of the presence of only two species of this group, D. varicus and C. adunca.

\section{Discussion}

The list of 57 macroparasite taxa reported in the present study (Additional file 1) comprises nearly $56 \%$ of the parasites found in G. morhua throughout its distributional range (a total of 97 species, resulting from compilation of data gathered as early as 1932 from both North West and North Eeast Atlantic, see [2]). It indicates a high regional richness of the metazoan parasites of cod in the North East Atlantic. These results conform to the diverse and non-selective diet of cod, its wide depth distribution and migratory behaviour. It is also possible that increased sampling effort has contributed to the high diversity of the parasite list reported here and this is supported by the seven new host records. Of these, only the gadoid specialist $D$. merlangi, which mainly parasitises whiting (Merlangius merlangus (L.), see [82]) belongs to the Arctic-Boreal category. The newly recorded helminth species mainly belong to generalist genera with a wide geographical dis- 
A

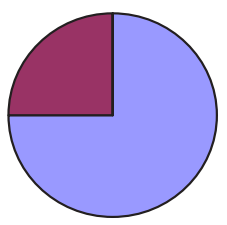

B



C

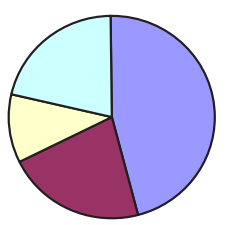

D

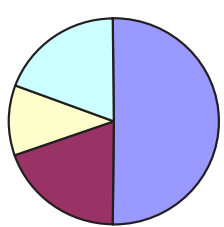

E

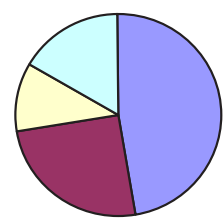

F

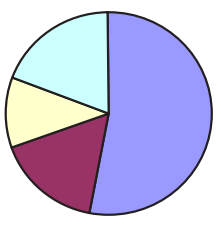

G

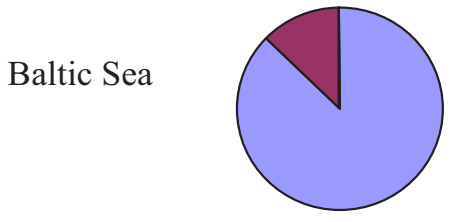

$\mathrm{H}$

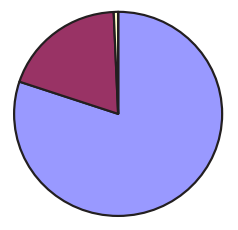

I

Celtic Sea



J

Icelandic waters

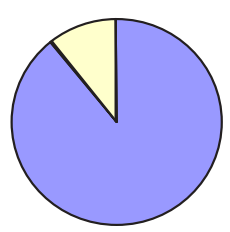

K

Irish Sea

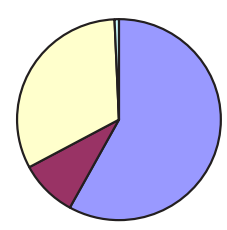

L

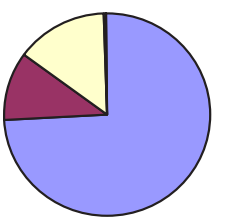

$\square$ Arctic-Boreal

a Boreal

$\square$ Worldwide

$\square$ Not aplicable

Figure 5

Relative richness (A-F) and abundance (G-L) structure of parasite faunas of G. morhua in the six North East Atlantic regions with respect to zoogeographical distribution of parasites. 
tribution whereas the copepod Chondracanthus ornatus is typical of calionomid perciforms [85]. The geographical distribution of the Callionymidae overlap with that of cod, thus its recovery indicates some interaction with calionomids.

However, the regional parasite faunas of cod exhibited a generally lower richness (63-65\% of the total list) with a notable decrease in the Baltic Sea and Trondheimsfjord (21 and 32\%, respectively). Parasites from all metazoan taxa were recorded in the present study, with eleven species present in all regions. The predominant higher taxa in the regional faunas in terms of number of species were trematodes and nematodes. However, the taxonomic structure of the faunas based on the relative abundance of the higher taxa revealed that nematodes (mostly anisakid larvae) represent the majority of all parasite individuals. This fact can be related to cod being a voracious predator, and with a long life-span, which facilitates larval accumulation).

The regional faunas exhibited differences with respect to both higher-level taxonomic structure and species-level comparisons. Generally, the fauna of the brackish-water regions [Baltic Sea (7-13.6\%o) and Trondheimsfjord (10$33 \%$ )] differed substantially from those in the high-salinity regions (Celtic, Irish and North seas and Icelandic waters, salinity range 34.2-35.4\%o). Although variation in fish size between regions may have contributed to the observed variability, the much lower species richness recorded in the former two regions agrees with the lower salinity conditions that restrict the distribution and richness of the invertebrate fauna and consequently limiting the diversity of successful parasite life-cycles $[87,88]$. Remarkably, none of the species characteristic of low salinity and freshwater distributions reported previously in cod (i.e. Podocotyle angulata (Dujardin, 1845), Raphidascaris acus (Bloch, 1779), Acanthocephalus lucii (Müller, 1777), Echinorhynchus salmonis (Müller, 1784), Neoechinorhynchus rutili (Müller, 1780) and Pomphorhynchus laevis (Zoega in Müller, 1776) $[2,87,89]$ ) was recorded in our collections from the Baltic Sea and Trondheimsfjord.

On the other hand, although both regional faunas consisted of marine parasite species, their structure differed from that of the faunas from the open water regions in: (i) the poorer numerical representation of nematodes; (ii) the absence of cestodes; (iii) the absence or low abundance of species with worldwide distribution; and (iv) the composition with respect to host specificity categories [i.e. the strong numerical domination of generalists (Baltic Sea fauna) or gadoid specialist species (Trondheimsfjord fauna)]. These differences, therefore, indicate different transmission conditions in the two low-salinity regions. This suggestion is further reinforced by the notably differ- ent structure of the faunas in the latter regions characterised by the numerical dominance of generalist acanthocephalans [mostly E. gadi (s. l.), Baltic Sea] or gadoid specialist trematodes (Lepidapedon spp., Trondheimsfjord).

The overall prevalence of $88.3 \%$ of E. gadi (s. l.) observed in the present study agrees well with the high levels of infection in cod recorded in previous studies: $71.4 \%$ in the southern Baltic Sea [90] and 99.4\% in the Bornholm Basin of Baltic Sea [37]. The mean intensities recorded here are similar (32.2 worms/host) to those in the latter study: 54.7 in smaller cod (21 to $30 \mathrm{~cm}$ body length) and 33.3 in larger cod (52 to $60 \mathrm{~cm}$ body length). Gammarid (Gammarus oceanicus) and caprellid (Monoporeia femorata) amphipods serve as intermediate hosts of E. gadi (s. l.) in the Baltic Sea [91]. Whereas the high infection levels in small cod may indicate that amphipods are an important component their diet, the heavy infection of large cod (> $61 \mathrm{~cm}$; normally not feeding on amphipods) was explained by a transfer of parasites from prey fish to the large cod [37]. It is possible that both processes contribute to the infection of cod in the Baltic Sea collection since the size of the fish studied ranged from 31.4 to $89.6 \mathrm{~cm}$ (SL).

The dominance of trematodes in the Trondheimsfjord fauna reflects the highest infection levels of two Lepidapedon species (see comparative data in Additional file 1). Both species belong to the subfamily Lepocreadiinae of the Lepocreadiidae Odhner, 1905, which are found either in deep-sea fishes or in fishes from cold, shallow waters, most usually in gadiforms [30]. Whereas the present data on the overall prevalence of $L$. elongatum $(60 \%)$ agree with previous observations in cod (up to $94.3 \%$ at various stations in Danish and adjacent waters [92]; up to $62 \%$ in juvenile $(0+)$ cod $[48,93-95]), L$. rachion has so far been recovered at much lower prevalences in various locations in the North East Atlantic (range 3.3-20\% vs 45\%, see [92]). Bray \& Gibson [30] listed a wider range of final hosts (mostly gadoids) in the North East Atlantic for the latter species (G. morhua, Melanogrammus aeglefinus, Merlangius merlangus, Pollachius pollachius, P. virens, Gymnacanthus tricuspis, Aspitrigla cuculus). Trondheimsfjord is characterised by a rich fish fauna (16 gadiform species including 10 species of gadoids: Gadiculus argenteus thori, G. morhua, M. aeglefinus, M. merlangus, Micromesistius poutassou, P. pollachius, P. virens, Trisopterus esmarki, T. minutus, Raniceps raninus; the latter uncommon, J.A. Sneli pers. comm.) and this may explain the higher infection levels of L. rachion in this region. It is also possible that the dominance of the two Lepidapedon species in the parasite fauna in cod from Trondheimsfjord is related to the presence of conditions enhancing completion of their life-cycles. The life-cycle of L. elongatum was elucidated by Køie [25]. The rediae and cercariae develop in the gastropod Onoba acu- 
leus and the metacercariae encyst in a variety of annelids; some may encyst in molluscs and echinoderms, but infections in these hosts are rare and probably short-lived [25]. The first intermediate host of $L$. rachion is believed to be Nassarius reticulatus and the metacercariae are said to occur in planktonic cnidarians, ctenophores, chaetognaths and polychaetes [26]. Sneli \& Gulliksen [96] reported both intermediate hosts, $\mathrm{O}$. aculeus and $\mathrm{N}$. reticulatus, in Trondheimsfjord. However, the life-cycle of $L$. rachion has not apparently been completed experimentally. Bray \& Gibson [30] considered the data on the second intermediate host puzzling, since the main final host of $L$. rachion, the haddock, Melanogrammus aeglefinus (L.), feeds as an adult almost entirely on benthic organisms. Nevertheless, cod studied at Trondheimsfjord were generally small-sized (SL range 16.5-48.0 cm) and it is possible that the proportion of small invertebrates in the diet of fish has contributed to the high representation of Lepidapedon spp.

Higher gadoid richness may also be associated with higher transmission rates which resulted in the dominance in the Trondheimsfjord fauna of the adult stages of two gadoid specialist nematodes, C. cirratus and C. gracilis. Final hosts of C. cirratus are Gadidae and Merluccidae, occasionally salmon, Salmo salar, see [97]). Although Anderson [70] suggests a direct infection of final host (by ingestion of free-living second-stage larvae, L2), calanoid (Acartia sp., Centropages sp., Temora sp.) and cyclopoid (Oitona similis) copepods and sand gobies, Pomatoschistus minutus, were found to serve as experimental intermediate hosts of C. cirratus [98]. Third-stage (L3) larva of C. gracilis hatch from the egg in the intestinal tract of either the intermediate fish host (sand goby, P. minutus; experimental data) or an invertebrate transport (paratenic) host [99]. Køie's [98] data, based on examination of 350 naturally infected cod (8-78 cm long), support this suggestion. She found that group 1 and older cod contained L3-stage larvae, intermediate stages and adult worms of $C$. cirratus, indicating that they could become infected throughout the year; however the pattern of infection suggested that cod over $20 \mathrm{~cm}$ long became infected mainly in summer by eating infected fish (including smaller cod). It is possible that the high infection levels with $C$. cirratus and $C$. gracilis in cod from Trondheimsfjord originate from ingestion of sand gobies which are common in the region.

One of the main results of the present study was the overall higher structural similarity of the parasite faunas in cod from Celtic, Irish and North seas and Icelandic waters, perhaps due to the similar oceanographic characteristics of these four regions. The domination of the generalist Arctic-Boreal anisakid nematodes [A. simplex (s. l.), C. osculatum (s. l.) and H. aduncum] represented a characteristic feature of the four regional faunas. A. simplex (s. l.) and C. osculatum (s. l.)] utilise marine mammal predators of cod $[2,71]$ as final hosts and follow a similar life history pattern.

Adult A. simplex (s.l.) have been reported in a large number of cetaceans and pinnipeds $[71,100]$. Eggs passed by marine mammals embryonate to the L2-stage larvae in sea water. When ingested by marine crustaceans (e.g. euphasiids, copepods) they develop to the L3 stage. Teleosts become infected by ingesting the first intermediate hosts see [70] and references therein. Klimpel et al. [101] studied the life-cycle of A. simplex in the northern North Sea and found that one copepod and four euphasiid species served as obligatory intermediate hosts. These authors revealed an obligatory second intermediate host, Maurolicus muelleri (Sternoptychidae), and stated that piscivorous (Pollacius virens, Melanogrammus aeglefinus, Etmopterus spinax) and planktivorous and juvenile fishes (Clupea harengus, Trisopterus esmarki, Melanogrammus aeglefinus) serve as paratenic hosts of $A$. simplex. Although the data on the life-cycle of C. osculatum species complex are somewhat wanting [70] copepods may appear important as intermediate hosts $[70,102])$.

Klimpel et al. [101] and Klöser et al. [103] suggested that A. simplex and C. osculatum, respectively, are able to utilise fish host species that are available in a given locality. This versatile behaviour coupled with the vagility of the final hosts, may explain the wide distribution and abundance of these species. H. aduncum possesses an even more resourceful life-cycle. Final hosts of this species are numerous predaceous teleosteans (clupeids, gadids, salmonids and others, see [97]). Third stage larvae develop in Acartia tonsa and harpacticoid copepods, various amphipods, isopods and mysids [104]. The latter can also serve as second intermediate hosts [105]. Furthermore, ctenophores, chaetognaths, polychaetes and ophiuroids which become infected by ingesting infected crustaceans, may act as obligatory intermediate hosts or paratenic (transport) hosts [104,106].

Despite their overall structural similarity, the four faunas could be grouped in two pairs, those from Celtic Sea and Icelandic waters $v s$ those from the Irish and North seas. It appears that the grouping with respect to the higher trematode representation in cod parasite faunas in Irish and North seas ( $v$ s Celtic Sea and Icelandic fauna) is related to the sampling locations. Thus, the fauna from deeper and ocean influenced locations in the Celtic Sea and Icelandic waters were dominated by nematodes whereas the more coastal and shallower locations (in the Irish and North seas) exhibited higher proportions of trematode individuals. 
Overall, generalist parasites with Arctic-Boreal or worldwide distribution comprised the best represented group of the cod parasite fauna with respect to both richness and numerical dominance (due to the presence of anisakid nematodes). This finding supports the conclusion of Hemmingsen \& MacKenzie [2] that cod acts as a distribution agent of generalist parasites in the North Atlantic because of its omnivorous diet, migratory behaviour and the mixture of stocks.

\section{Conclusion}

To summarise, our study reveals relatively rich and abundant regional macroparasite faunas in cod from the North East Atlantic which are generally dominated by generalist parasites with Arctic-Boreal distribution. Furthermore, it provides more detailed data on the distribution in the North East Atlantic of the majority of cod parasites which may serve as baselines for future studies on the effect of climate change on parasite distribution in abundance since the regions occupied by cod are expected to experience some of the largest anthropogenic climate changes in the world. The higher-level faunal comparisons suggest that differences may exist in the feeding behaviour between cod sampled in the six regions. On the other hand, the composition of the regional faunas may be determined largely by variations in the abundance of the intermediate hosts. These suggestions are supported by the high regional variation in the prevalence and abundance of the parasite species which translated into somewhat different clustering pattern based on similarity at the species level. Finally, based on the above comparisons, the following predictions can be made in relation to the structure and diversity of the parasite communities:

(i) Parasite communities in cod from the Baltic Sea and Trondheimsfjord would show much lower richness, abundance, diversity and would exhibit higher variation in composition and structure.

(ii) Parasite communities in cod from the other four regions (Irish, Celtic and North seas and Icelandic waters) would have the highest richness, abundance, diversity and similarity and would be dominated by larval nematodes.

(iii) With 11 species (nearly a fifth of the total number) shared between the six regions there would be a substantial homogenisation in the composition of both the component and infracommunities. A. simplex (s. l.), $H$. aduncum and D. varicus would contribute substantially to the structural homogeneity between communities.

\section{Competing interests}

The authors declare that they have no competing interests.

\section{Authors' contributions}

DPA and FEM carried out the parasitological examination of fish and the identification of the parasites. DPA performed the comparisons and drafted the manuscript. JAR and AK contributed to the design of the study, assisted in data interpretation and helped to draft the manuscript. All authors read and approved the final manuscript.

\section{Additional material}

\section{Additional file 1}

Host specificity, distribution, prevalence $(P)$, mean abundance $(M A \pm$ $S D)$, median abundance $(M$, shown if $>0$ only) of parasites in $G$. morhua from the Baltic, Celtic, Irish and North seas, Icelandic waters and Trondheimsfjord (Norway). New host records are marked with an asterisk. Abbreviations for host specificity categories: D: food content; $G$, generalist; $G S$, gadoid specialist.Abbreviations for distribution categories: A-B, Arctic-Boreal; B, Boreal; W, worldwide; NA, Not applicable.

Click here for file

[http://www.biomedcentral.com/content/supplementary/17563305-1-23-S1.doc]

\section{Acknowledgements}

Thanks are due to the CODTRACE team, especially to Dr Juan Antonio Balbuena, and the rest of the Marine Zoology Unit (Cavanilles Institute of Biodiversity and Evolutionary Biology, University of Valencia) for technical assistance and Patricia Gozalbes for her help with the map and the references. We are grateful to Professor Chris Arme who kindly corrected the English and the three reviewers for their important comments and suggestions. Sampling and identification of cod parasites was developed under the European Union funded project CODTRACE (Q5RS-200I-01697). DPA benefited from a PhD fellowship by Generalitat Valenciana; AK was supported by a Marie Curie grant FP6-MTKD-CT-2004-003I75 to JAR; FEM was supported by a 'Juan de la Cierva' contract (MCYT, Spain).

\section{References}

I. Kurlansky M: Cod. A biography of the fish that changed the world London: Jonathan Cape; 1998.

2. Hemmingsen W, MacKenzie K: The parasite fauna of the Atlantic cod, Gadus morhua L. Adv Marine Biol 200I, 40:I-80.

3. Des Clers S: Modelling regional differences in "sealworm" Pseudoterranova decipiens (Nematoda, Ascaridoidea) infections in some North Atlantic cod, Gadus morhua, stocks. J Fish Biol 1989, 35:187-192.

4. Des Clers S: Functional relationship between sealworm (Pseudoterranova decipiens, Nematoda, Ascaridoidea) burden and host size in Atlantic cod (Gadus morhua). Proc Royal Soc London B 1991, 245:85-89.

5. Brattey J, Bishop CA: Larval Anisakis simplex (Nematoda: Ascaridoidea) infection in the musculature of Atlantic cod, Gadus morhua, from Newfoundland and Labrador. Can Bull Fish Aquat Sci 1992, 49:2635-2647.

6. Jensen T, Idas K: Infection with Pseudoterranova decipiens (Krabbe, 1878) larvae in cod (Gadus morhua) relative to proximity of seal colonies. Sarsia 1992, 76:227-230.

7. Rokicki J, Valter ED, Myjak P: Contracaecum osculatum (Nematoda, Anisakidae) in cod, Gadus morhua L. from the Polish coast of the Baltic. Acta Parasitol 1993, 38:33-35.

8. McClelland G, Marcogliese DJ: Larval anisakine nematodes as biological indicators of cod (Gadus morhua) populations in the southern Gulf of St. Lawrence and on the Breton Shelf, Canada. Bull Scand Soc Parasitol I994, 4:97-I I6. 
9. Myjak P, Szostakowska B, Wojciechowski J, Pietkiewicz H, Rokicki J: Anisakid larvae in cod from the southern Baltic Sea. Arch Fish Mar Res 1994, 42:149-161.

10. Boily F, Marcogliese DJ: Geographical variations in abundance of larval anisakine nematodes in Atlantic cod (Gadus morhua) and American plaice (Hippoglossoides platessoides) from the Gulf of St. Lawrence. Can J Fish Aquat Sci 1995, 52: I05-I I 5

II. Hemmingsen W, Lile N, Halvorsen O: Search for seasonality in occurrence of parasites of cod, Gadus morhua $L$. in a fjord at 70 deg N. Polar Biol 1995, I 5:517-522.

12. Petter AJ, Cabaret J: Ascaridoid nematodes of teleostean fishes from the Eastern North Atlantic and seas of the North of Europe. Parasite 1995, 2:217-230.

13. Brattey J, Davidson WS: Genetic variation within Pseudoterranova decipiens (Nematoda: Ascaridoidea) from Canadian Atlantic marine fishes and seals: characterization by RFLP analysis of genomic DNA. Can J Fish Aquat Sci 1996, 53:333-34I.

14. Jensen $\mathrm{T}$ : Experimental infection/transmission of sculpins (Myoxocephalus scorpius) and cod (Gadus morhua) by sealworm (Pseudoterranova decipiens) larvae. Parasitol Res 1997, 83:380-382

I5. Balbuena JA, Karlsbakk E, Saksvik M, Kvenseth AM, Nylund A: New data on the early development of Hysterothylacium aduncum (Nematoda, Anisakidae). J Parasitol 1998, 84(3):615-6I7.

16. Stromnes E, Andersen K: Distribution of whaleworm (Anisakis simplex, Nematoda, Ascaridoidea) L3 larvae in three species of marine fish; saithe (Pollachius virens (L.), cod (Gadus morhua L.) and redfish (Sebastes marinus (L.) from Norwegian waters. Parasitol Res 1998, 84(4):28I-285.

17. Stromnes E, Andersen K: "Spring rise" of Whaleworm (Anisakis simplex; Nematoda, Ascaridoidea) third-stage larvae in some fish species from Norwegian waters. Parasitol Res 2000 , 86(8):619-624.

18. Stromnes E, Andersen K: Growth of whaleworm (Anisakis simplex, Nematodes, Ascaridoidea, Anisakidae) third-stage larvae in paratenic fish hosts. Parasitol Res 2003, 89(5):335-34I.

19. Khan RA, Lee EM: Influence of Lernaeocera branchialis (Crustacea: Copepoda) on growth rate of Atlantic cod, Gadus morhua. J Parasitol 1989, 75(3):449-454.

20. Khan RA, Ryan K, Barker DE, Lee EM: Effect of a single Lernaeocera branchialis (Copepoda) on growth of Atlantic cod. J Parasitol 1993, 79(6): 954-958.

21. Kulachkova VG, Timofeeva TA: Gyrodactylus pterygialis Bychowsky et Poljansky, 1953 from the Kildin cod of Lake Mogil'noe. In Investigation of Monogeneans in the USSR Edited by: Skarlato OA. Leningrad: Zoological Institute, of the USSR Academy of Sciences; 1987:44-50.

22. Appleby C: Seasonal occurrence, topographical distribution and transmission of Gyrodactilus callariatis (Monogenea) infecting juvenile Atlantic cod in the Oslo Fjord, Norway. J Fish Biol 1996, 48: I266-1274.

23. MacKenzie K, Kalavati C, Gaard M, Hemmingsen W: Myxosporean gall bladder parasites of gadid fishes in the North Atlantic: their geographical distributions and an assessment of their economic importance in fisheries and mariculture. Fish Res 2005, 76:454-465.

24. Karlsbakk E, Haugen E, Nylund A: Morphology and aspects of growth of a trypanosome transmitted by the marine leech Johanssonia arctica (Piscicolidae) from Northern Norway. Folia Parasitol (Praha) 2005, 52(3):209-2I5.

25. Køie $M$ : On the morphology and life-cycle of Lepidapedon elongatum (Lebour, 1908) Nicoll, 1910 (Trematoda, Lepocreadiidae). Ophelia I985, 24: I35-I53.

26. Køie $M$ : The surface topography and life-cycles of digenetic trematodes in Limanda limanda (L.) and Gadus morhua L. In $\mathrm{PhD}$ thesis University of Copenhagen. Helsingør: Marine Biological Laboratory; 1985.

27. Bray RA, Gibson DI: The Acanthocolpidae (Digenea) of fishes from the north-east Atlantic: the status of Neophasis Stafford, 1904 (Digenea) and study of North Atlantic forms. Syst Parasitol 1991, 19:95-117.

28. MacKenzie K: Massive infections of cod, Gadus morhua L., in the Firth of Clyde with metacercariae of the digenean Bucephaloides gracilescens (Rudolphi, I819). Bull Eur Assoc Fish Pathol 199|, I I:125-126.
29. Bray RA, Des Clers S: Multivariate analyses of metrical features in the Lepidapedon elongatum (Lebour, 1908) species complex (Digenea, Lepocreadiidae) in deep and shallow water gadiform fishes of the NE Atlantic. Syst Parasitol 1992, 2I:223-232.

30. Bray RA, Gibson DI: The Lepocreadiidae (Digenea) of fishes from the north-east Atlantic: a review of the genus Lepidapedon Stafford, 1904. Syst Parasitol 1995, 3 1:81-132.

3I. Gaevskaya AV: On Lepidapedon elongatum (Trematoda, Lepocreadiidae) and its synonyms. Zool Zhurnal 1996, 75:770-773.

32. Lysne DA, Hemmingsen W, Skorping A: The distribution of Cryptocotyle spp. metacercariae in the skin of caged Atlantic cod (Gadus morhua). J Fish Biol 1994, 45:352-355.

33. Lysne DA, Hemmingsen W, Skorping A: Regulation of intrapopulations of Cryptocotyle lingua on cod. Parasitology 1997, I | 4: | $45-150$

34. Perdiguero-Alonso D, Montero FE, Raga JA, Balbuena JA: Diclidophora merlangi (Monogenea: Diclidophoridae) on Atlantic cod, Gadus morhua. J Parasitol 2006, 92(4):697-702.

35. Buchmann K: On the infection of Baltic cod (Gadus morhua L.) by the acanthocephalan Echinorhynchus gadi (Zoega) Müller. Scand J Vet Sci 1986, 38:308-314.

36. Buchmann K: Variations of the infection level of Echinorhynchus gadi (Acanthocephala) in Baltic cod (Gadus morhua). Bull Eur Assoc Fish Pathol 1988, 8: I 1-13.

37. Buchmann K: Ecological implications of Echinorhynchus gadi parasitism of Baltic cod (Gadus morhua). J Fish Biol 1995, 46:539-540.

38. Valtonen ET, Crompton DWT: Acanthocephala in fish from the Bothnian Bay, Finland. J Zool 1990, 220:619-639.

39. Wayland MT, Gibson DI, Sommerville C: Morphometric discrimination of two allozymically diagnosed sibling species of the Echinorhynchus gadi Zoega in Müller complex (Acanthocephala) in the North Sea. Syst Parasitol 2005, 60:139-149.

40. Sherman K, Wise JP: Incidence of the cod parasite Lernaeocera branchialis $L$. in the New England area, and its possible use as an indicator of cod populations. Limnol Oceanogr |96|, 6:6 |-67.

41. Templeman W, Fleming AM: Distribution of Lernaeocera branchialis (L.) on cod as an indicator of cod movements in the Newfoundland area. ICNAF special publication 1963, 4:318-322.

42. Platt NE: Codworm - a possible biological indicator of the degree of mixing of Greenland and Iceland cod stocks. J Conseil 1976, 37:41-45.

43. Templeman W, Hodder VM, Fleming AM: Infection of Iumpfish (Cyclopterus lumpus) with larvae and of Atlantic cod (Gadus morhua) with adults of the copepod, Lernaeocera branchialis, in and adjacent to the Newfoundland area, and inferences therefrom on inshore-offshore migrations of cod. I Fish Res Board Can 1976, 33:7||-731.

44. Khan RA, Murphy J, Taylor D: Prevalence of a trypanosome in Atlantic cod (Gadus morhua) especially in relation to stocks in the Newfoundland area. Can J Fish Aquat Sci 1980, 37:1467-1475.

45. Boje J: Parasites as natural tags on cod (Gadus morhua L.) in Greenland waters. In Parasites and Diseases in Natural Waters and Aquaculture in Nordic countries Edited by: Stenmark A, Malmberg G. Stockholm: Zootax, Naturhistoriska Riksmuseet; 1987:94-I0I.

46. Bishop CA, Lear WH, Baird JW, Wells R: Comparison of cod samples from St Pierre Bank and Rose Blanche Bank from analysis of meristic characters, average length at age, and prevalence of parasitic nematodes. NAFO Sci Council Res Doc 1988, 88/70:7.

47. Khan RA, Tuck C: Parasites as biological indicators of stocks of Atlantic cod (Gadus morhua) off Newfoundland, Canada. Can J Fish Aquat Sci 1995, 52:195-201.

48. Polyansky $\mathrm{YI}, \mathrm{Kulemina}$ IV: The parasite fauna of young cod from the Barents Sea. Vestnik Leningr Univ, Ser Biol 1963, 30: I 74-192. [in Russian]

49. Reimer LW: Digene Trematoden und Cestoden der Ostseefische als natürliche Fischmarken. Parasitol Schriften 1970 , 20:5-137.

50. Hemmingsen W, Lombardo I, MacKenzie K: Parasites as biological tags for cod, Gadus morhua L., in northern Norway. a pilot study. Fish Res 1991, I 2:365-373. 
51. Karasev $A B$ : Use of parasites as biological tags when studying intraspecific structure of cod in the coastal areas of Russia and Norway. Bull Scand Soc Parasitol 1994, 4:17.

52. Karasev $A B$ : On the use of parasites in studies of Arcto-Norwegian cod population structure. In Parasites and Diseases of Marine and Freshwater Fishes of the North Basin: Selected Papers Edited by: Karasev AB. Murmansk: PINRO Press; 1998:22-33. [In Russian]

53. Larsen G, Hemmingsen W, Mackenzie K, Lysne DA: A population study of cod, Gadus morhua L., in northern Norway using otolith structure and parasite tags. Fish Res 1997, 32:13-20.

54. Hemmingsen W, Lile NK, Halvorsen O: The parasite fauna of cod (Gadus morhua L.) in Balsfjord, North Norway. Polar Biol I992, 1 2:739-742.

55. Hemmingsen $W$, Halvorsen $O$, MacKenzie K: The occurrence of some metazoan parasites of Atlantic cod, Gadus morhua $\mathrm{L}$. in relation to age and sex of the host in Balsfjord ( $70 \mathrm{deg} \mathrm{N}$ ), North Norway. Polar Biol 2000, 23:368-372.

56. ICES: Spawning and life history information for North Atlantic cod stocks. ICES Cooperative Research Report 2005, 274:152.

57. Brinkmann AJ: Trematodes from Greenland. Meddelelser om Grønland 1975, 205: I-88.

58. Bray RA: Some digenetic trematodes in fishes from the Bay of Biscay and nearby waters. Bull British Mus (Nat Hist) Zool 1973 , 26: $15 \mid-183$

59. Bray RA, Cribb TH: Species of Stephanostomum Looss, 1899 (Digenea: Acanthocolpidae) from fishes of Australian and South Pacific waters, including five new species. Syst Parasitol 2003, 55(3):159-197.

60. Køie M: Digenetic trematodes from Gadus morhua $L$ (Osteichthyes, Gadidae) from Danish and adjacent waters, with special reference to their life-histories. Ophelia 1984, 23:195-222

61. Bartoli P, Bray RA: Contribution to the knowledge of species of the genus Stephanostomum Looss, 1899 (Digenea: Acanthocolpidae) from teleosts of the western Mediterranean, with the description of S. gaidropsari n. sp. Syst Parasitol 200I, 49(3): $159-188$.

62. Karlsbakk $E$ : On the morphology and ecology of some digenean parasites of the four-bearded rockling (Enchelyopus cimbrius (L.) (Gadidae) in Raunefjorden, western Norway. In PhD thesis University of Bergen; 1993.

63. Williams PH: Some observations on Parabothium gadi-pollachii (Rudolphi, I8I0) and Abothrium gadi van Beneden 1870 (Cestoda: Pseudophyllidea) including an account of their mode of attachment and variation in the two species. Parasitology 1960, 50:303-322.

64. Bray RA, Jones A, Andersen HI: Order Pseudophyllidea. In Keys to the cestode parasites of vertebrates Edited by: Khalil LF, Jones A, Bray RA. Wallingford: CAB Intemational:205-249.

65. Olson AC, Lewis MD, Hauser ML: Proper identification of anisakine worms. Amer J Med Technol I983, 49(2): I I I-I I4.

66. Fagerholm HP: Incubation in rats of a nematodal larva from cod to establish its specific identity: Contracaecum osculatum (Rudolphi). Parasitol Res 1988, 75:57-63.

67. Dick TA, Dixon BR, Choudhury A: Diphyllobothrium, Anisakis and other fish-borne parasitic zoonoses. Southeast Asian J Trop Med Public Health 1991, 22: I50- 152.

68. Mattiucci S, Nascetti G: Molecular systematics, phylogeny and ecology of anisakid nematodes of the genus Anisakis Dujardin, 1845: an update. Parasite 2006, 13:99-1। 3.

69. Mattiucci S, Nascetti G, Cianchi R, Paggi L, Arduino P, Margolis L, Brattey J, Webb S, D'Amelio S, Orecchia P, Bullini L: Genetic and ecological data on the Anisakis simplex complex, with evidence for a new species (Nematoda, Ascaridoidea, Anisakidae). J Parasitol 1997, 83:40I-416.

70. Anderson RC: Nematodes parasites of vertebrates. Their development and transmission 2nd edition. Wallingford: CABI Publishing; 2000.

71. Mattiucci S, Nascetti G: Advances and trends in the molecular systematics of anisakid nematodes, with implications for their evolutionary ecology and host-parasite co-evolutionary processes. Adv Parasitol 2008, 66:47-148.

72. Mattiucci S, Paggi L: Multilocus electrophoresis for the identification of larval Anisakis simplex A and B and Pseudoterranova decipiens A, B and C from fish. Nematode problems in North Atlantic fish. ICES Report from a workshop in Kiel C.M./F 1989, 6:23.
73. Paggi L, Nascetti G, Cianchi R, Orecchia P, Mattiucci S, D'Amelio S, Berland B, Brattey J, Smith JW, Bullini L: Genetic evidence for three species within Pseudoterranova decipiens (Nematoda: Ascaridida, Ascaridoidea) in the North Atlantic and Norwegian and Barents Seas. Int J Parasitol I991, 21:195-212.

74. Nascetti G, Cianchi R, Mattiucci S, D'Amelio S, Orecchia P, Paggi L, Brattey L, Berland B, Smith JW, Bullini L: Three sibling species within Contracaecum osculatum (Nematoda, Ascarida, Ascaridoidea) from the Atlantic Artic-Boreal region: reproductive isolation and host preferences. Int J Parasitol 1993, 23:105-120.

75. Orecchia P, Mattiucci S, D'Amelio S, Paggi L, Plötz J, Cianchi R, Nascetti G, Arduino P, Bullini L: Two new members in the Contracaecum osculatum complex (Nematoda, Ascaridoidea) from the Antarctic. Int J Parasitol 1994, 24:367-377.

76. Berland B: Hysterothylacium aduncum (Nematoda) in fish. ICES Identification leaflets for diseases and parasites of fish and shellfish 1991, 44:I-4.

77. Køie M: Nematode parasites in teleosts from 0 to $1540 \mathrm{~m}$ depth off the Faroe islands (The North Atlantic). Ophelia 1993, 38:217-243.

78. Janiszewska J: Studien über die Entwicklung und die Lebensweise der parasitischen Würmer in der Flunder (Pleuronectis flesus L.). Mém 'Academie Polon Sci, Ser B, Sci naturelles 1938, 24: I -68.

79. Palm HW, Klimpel S, Bucher C: Checklist of metazoan fish parasites of German coastal waters. Berichte aus dem institut für Meereskunde an der Christian-Albrechts-Universität, Kiel 307: 148.

80. Gibson DI, Bray RA, Harris EA: Host-Parasite Database of the Natural History Museum, London. [http://www.nhm.ac.uk/ research-curation/projects/host-parasites/.]. Compilers: 2005

8I. Väinolä R, Valtonen ET, Gibson DI: Molecular systematics in the acanthocephalan genus Echinorhynchus (sensu lato) in northern Europe. Parasitology 1994, 108:105-I I4.

82. Rubec LA, Dronen NO: Revision of the genus Diclidophoro Krøyer, 1838 (Monogenea: Diclidophoridae), with the proposal of Macrouridophora n. g. Syst Parasitol 1994, 28:159-185.

83. Gibson DI, Bray RA: The Hemiuridae (Digenea) of fishes from the north-east Atlantic. Bull Brit Mus (Nat Hist) Zool 1986, 5I:I-I25.

84. Appy RG, Dadswell MJ: Marine and estuarine piscicolid leeches (Hirudinea) of the Bay of Fundy and adjacent waters with a key to species. Can J Zool I98I, 59:183-192.

85. Kabata K: Parasitic copepoda of British fishes London: The Ray Society; 1979.

86. Lawrence MJ, Keast MA: Benthic Isopoda from the Southern Beaufort Sea and Central and Arctic Region. Can Manuscr Rep Fish Aquat Sci 1990, 2048: 1-76.

87. Zander CD: Ecology of host-parasite relationships in the Baltic Sea. Naturwissenschaften 1998, 85:426-436.

88. Zander $C D$, Reimer LW: Parasitism at the ecosystem level in the Baltic Sea. Parasitology 2002, I 24:SI I 9-SI35.

89. Pilecka-Rapacz M, Sobecka E: Parasites of young Baltic cod, Gadus morhua callarias L. in the Gulf of Puck, Poland. Acta Ichth Piscat 2004, 34:235-240.

90. Reimer LW, Walter U: On the parasitisation of Gadus morhua in the southern Baltic Sea. Appl Parasitol 1993, 34:181-186. [In German]

91. Valtonen ET, Pulkkinen K, Poulin R, Julkunen M: The structure of parasite component communities in brackish water fishes of the northeastern Baltic Sea. Parasitology 200I, I 22:47I-48I.

92. Køie M: Digenetic trematodes from Gadus morhua $L$. (Osteichthyes, Gadidae) from Danish and adjacent waters, with special reference to their life-histories. Ophelia 1984, 23:195-222.

93. Polyansky YI, Shulman SS: Changes in the parasite fauna of fishes with age. Trudy Karelo-Finskogo Filiala Akademii Nauk SSR 1956, 4:3-26. [In Russian]

94. Karasev $A B$ : Parasitological investigations on 0-group cod in the Barents Sea in the autumn and winter of 1979/1980. Ann Biol 1983, 37:126-127.

95. Karasev $A B$ : Parasitological investigations on 0-group cod in the Barents Sea in the autumn and winter of $1980 / 1981$. Ann Biol 1983, 38:91.

96. Sneli JA, Gulliksen B: Prosobranch molluscs and ascidians in the Trondheimsfjord 197 I-1 973. In Zoologisk rapport Norges teknisknaturvitenskapelige universitet Vitenskapsmuseet; 2006:61. 
97. Moravec F: Parasitic nematodes of Freshwater Fishes of Europe Dordrecht: Kluwer Academic Publishers; 1994.

98. Koie M: Life cycle and seasonal dynamics of Cucullanus cirratus Müller, 1777 (Nematoda, Ascaridida, Seuratoidea, Cucullanidae) in Atlantic cod, Gadus morhua L. Can J Zool 2000, 78: $182-190$.

99. Køie M: The life-cylce of Capillaria gracilis (Capillariidae), a nematode parasite of gadoid fish. Sarsia 2001, 86:383-387.

100. Davey JT: A revision of the genus Anisakis Dujardin, 1845 (Nematoda: Ascaridata). J Helm 1971, 14:5I-72.

101. Klimpel S, Palm HW, Ruckert S, Piatkowski U: The life cycle of Anisakis simplex in the Norwegian Deep (northern North Sea). Parasitol Res 2004, 94: I-9.

102. Koie M, Fagerholm H-P: Third-stage larvae emerge from eggs of Contracaecum osculatum (Nematoda, Anisakidae). J Parasitol 1993, 79:777-780.

103. Klöser H, Plötz J, Palm H, Bartsch A, Hubold G: Adjustment of anisakid nematode life cycles to the high Antarctic food web as shown by Contracaecum radiatum and $C$. osculatum in the Weddell sea. Antarctic Sci 1992, 4: I7I-178.

104. Køie M: Aspects of the life cycle and morphology of Hysterothylacium aduncum (Rudolphi, 1802) (Nematoda, Ascaridoidea, Anisakidae). Can J Zool 1993, 71:1289-1296.

105. Klimpel S, Palm HW, Seehagen A: Metazoan parasites and food composition of juvenile Etmopterus spinax (L., I758) (Dalatiidae, Squaliformes) from the Norwegian Deep. Parasitol Res 2003, 89:245-25I.

106. Margolis L: Polychaetes as intermediate hosts of helminths parasites of vertebrates: a review. J Fisher Res Board Can 197I, 28:1385-1392.

Publish with Bio Med Central and every scientist can read your work free of charge

"BioMed Central will be the most significant development for disseminating the results of biomedical research in our lifetime. "

Sir Paul Nurse, Cancer Research UK

Your research papers will be:

- available free of charge to the entire biomedical community

- peer reviewed and published immediately upon acceptance

- cited in PubMed and archived on PubMed Central

- yours - you keep the copyright

Submit your manuscript here:

http://www.biomedcentral.com/info/publishing_adv.asp
BioMedcentral 